\title{
Validating and Testing Learning Transfer System Inventory (LTSI) in a Developing Country Context: A Case of Pakistan's Service Sector
}

\author{
ZEESHAN HUSSAIN \\ MS-Scholar, City University of Science and Information Technology, Peshawar, Pakistan
}

zeemix1@yahoo.com

MUHAMMAD NAUMAN HABIB

Assistant Professor/ Head of Department, Management Sciences, City University of Science and Information Technology, Peshawar, Pakistan

Habib_nauman@hotmail.com

ZUNNOORAIN KHAN

Assistant Professor, City University of Science and Information Technology, Peshawar,

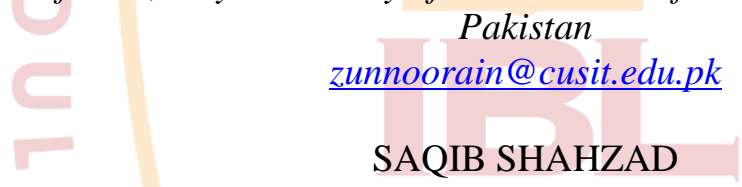

PhD-Scholar, Institute of Business Studies and Leadership

Abdul Wali Khan University, Mardan

Saqibshahzad26@gmail.com

\begin{abstract}
Learning Transfer System Inventory (LTSI) is a tool used to measure the impact of various factors on learning outcomes. The objective of the study was to understand the problems faced by Pakistan service sector employees and finally to evaluate the impact of motivation scale, environment scale and trainee ability scale on outcome scale.Questionnaire of Learning Transfer System Inventory adopted from Holton, Bates and Ruona (2000) was used.569 questionnaires were administered to the employees of Peshawar service sector including employees of banks, non-government organizations, education and health sectors, out of which 415 were completed with a response rate of $73 \%$. Correlation analysis shows that value of $R$ is 0.969 that means there is $96.9 \%$ correlation in variables that are considered in model. The value of $R$ Square is 0.939. In Service Sector, Supervisor Sanction Variable, Performance Outcome Expectation Variable and Performance Coaching Variable are insignificant and do not bring change in our dependent variable Outcome. Standardized Coefficients show that Personal Capacity for Transfer Variable, Peer Support Variable, Supervisor Support Variable and Transfer Effort Performance Expectation Variable having higher Standardized Coefficients betas, that means those variables bring greater change in dependent variable Outcome.
\end{abstract}

Key Words: LTSI, Learning, Training, Public Sector, Quantitative 


\section{Introduction}

Human resource is considered the most important factor of production and can lead to enhanced organizational development, only if human resource is sufficiently trained. Skills gaps (supply chain of skills) remains to be a challenging problem for companies. Investment in training is important for stakeholders including employees, businesses, and job seekers. Pinpointing a skill gap can be difficult. Different employees have different strengths and weaknesses and it takes time to know the deficiency of each employee. Organizations need to develop training programs so that over time, each and every employee becomes proficient at his or her job (Bersin, 2014). Proper training results in better learning transfer for employees. Learning transfer means how individuals, trainees would transfer learning in one context to another (Baldwin, Ford \& Blume, 2009). Learning transfer can be examined by LTSI adopted from Holton, Bates and Ruona (2000). LTSI is a sixteen factor model and those sixteen factors are categorized into five scales namely secondary influences scale, motivation scale, environment scale, ability scale and outcome scale. Secondary influences scale examines trainee attitude prior to and during training. Motivational scale examines trainee motivational level with respect to training and with respect to applying learning after training is completed in work place. Environment scale examines the effect of supervisor support, peer support and other environmental factors on trainee learning. Ability scale examine the effect of training design content validity, overall training transfer design on outcome scale. Outcome scale is the overall outcome of the above four scale that constitute learning, individual performance and finally organizational performance. LTSI is used in developed world (Bates and Khasawneh, 2005) but has not been used in countries like India, Pakistan, Bangladesh and many other developing countries.

\subsection{Problem Statement}

A significant research gap lies with respect to using LTSI on Pakistan service sector. As LTSI is not completely validated, so LTSI needs to be validated on Pakistan service sector, if not completely then at least in parts. Those factors that are validated will be considered and used on Pakistan service sector to know the problems faced by employees in service sector with respect to learning transfer.

\subsection{Research Question}

- How to validate LTSI on Pakistan service sector and to understand the problems faced by Pakistan service sector employees and finally to evaluate the impact of motivation scale, environment scale and trainee ability scale on outcome scale?

\subsection{Objectives of the Study}

- To validate LTSI on Pakistan service sector.

- To evaluate the impact of motivation scale on outcome scale.

- To evaluate the impact of environment scale on outcome scale.

- To identify the impact of trainee ability scale on outcome scale.

\section{Literature Review}

Training means acquiring knowledge, skills and individual abilities to properly do a job that result from vocational teaching or practical skills (Whitebread et al., 2009). There are several benefits of training such as; an employee acquires knowledge and skills that enhance his ability to do job properly (Grossman and Salas, 2011).Training results in time efficiency as employee can properly complete tasks in short period of time 
(Hutchins and Burke, 2006).On-the-job training method is very beneficial for vocational work (Kirwan \& Birchall, 2006).Off-the-job training allows employees to get away from job work and fully concentrate on the training. Such training is more effective in learning concepts and ideas (Riege, 2007). Velada et al. (2007) looked at the impact of several independent variables that are transfer design, performance self-efficacy, supervisor support, feedback and training retention on dependent variable that is training transfer. Sample size of 336 staff was selected from nine large stores of a grocery market in Portugal, with 182 successful responses. For variable measurement 5-point Likert scale was used. For analysis EFA was performed, PCA was also performed. Results show that performance self-efficacy, transfer design, retention and feedback were considerably associated to training transfer. On the other hand, supervisory support was not considerably linked to training transfer.

Coetsee et al. (2006) looked at the impact of all LTSI Independent variables on dependent variable. Study used convenience sampling technique used on South African employees undergoing training. Study used sample size of 240 of the Home Loan Section of Banking. There were 221 usable responses. Statistical analysis performed to identify latent variables of the LTSI using EFA. The KMO statistic for 78 questions was 0,857 . Results showed that seventeen items accounted for $71 \%$ of the variation out of 78 items. Chen (2003) considered all LTSI Independent and dependent variables. There were 712 questionnaires distributed among twenty organizations. Organizations from public sector included ( $\left.\mathrm{N}_{-} 77\right)$, educational institutes $\left(\mathrm{N}_{-} 59\right)$, private sector $\left(\mathrm{N}_{-} 267\right)$, nonprofit ( $\mathrm{N}$ _ 100), and public for-profit ( $\mathrm{N}_{-} 63$ ) organizations. There were 577 usable responses. Exploratory factor analysis (EFA) and confirmatory factor analysis (CFA) were used. Results showed that non-profit organization show stronger transfer system compared to other organizational types. Devos et al. (2007) considered all LTSI Independent variables impact on dependent variable. The LTSI had been administered to 328 trainees and the questionnaire was filled by 106 of those participants one to three months later. For statistical analysis principal component analysis (PCA) was used. Results showed that seven variables were statistically significant with transfer: opportunity to use, learner readiness and motivation to transfer learning, transfer-performance, performanceoutcomes, transfer design and self-efficacy. 


\section{Theoretical Framework}

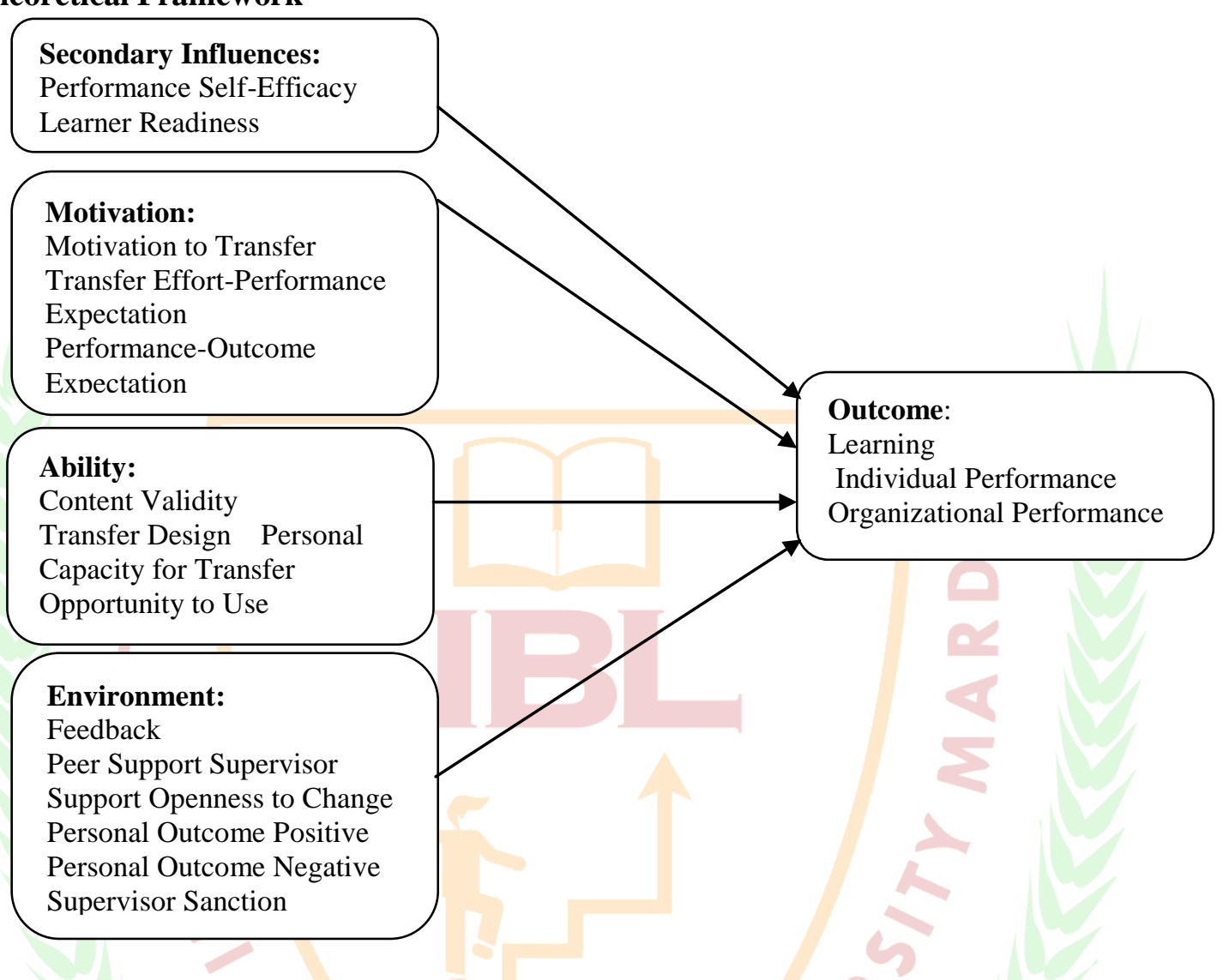

\section{Hypotheses}

Adopted from: Holton, Bates and Ruona (2000)

Based on the theoretical ground for variables, overview of the hypothesis related to the relationship between Outcome and sixteen LTSI variables have been established. On the base of dependent and independent variables, for this study sixteen hypothesis has been developed given below:

H1a: Performance Self Efficacy has significant effect on Outcome.

H1b: Learner Readiness has significant effect on Outcome.

H2a: Motivation to Transfer has significant effect on Outcome.

H2b: Transfer Effort Performance Expectation has significant effect on Outcome.

$\mathrm{H} 2 \mathrm{c}$ : Performance Outcome Expectation has significant effect on Outcome.

H3a: Performance Coaching has significant effect on Outcome.

H3b: Peer Support has significant effect on Outcome.

H3c: Supervisor Support has significant effect on Outcome.

H3d: Openness to Change has significant effect on Outcome.

H3e: Personal Outcome Positive has significant effect on Outcome.

H3f: Personal Outcome Negative has significant effect on Outcome.

H3g: Supervisor Sanction has significant effect on Outcome. 
H4a: Perceived Content Validity has significant effect on Outcome.

H4b: Transfer Design has significant effect on Outcome.

H4c: Personal Capacity for Transfer has significant effect on Outcome.

H4d: Opportunity to Use Learning has significant effect on Outcome.

\section{Methodology}

\subsection{Sampling Design}

\subsubsection{Population}

The population of the study was the employees of Pakistan service sector. In service sector Education, Healthcare, social work done by NGO's, and Banks were considered.

\subsubsection{Sample Size}

A sample size of 569 was extracted from population that fits the above mentioned criteria. This approach was used by Chen (2003).

\subsection{Research Instrument}

In survey method, questionnaire method adopted for data collection process. Questionnaire of Learning Transfer System Inventory adopted from Holton, Bates and Ruona (2000). LTSI is a sixteen factor model having 89 items.

\subsection{Data Collection Tool}

Questionnaire of Learning Transfer System Inventory adopted from Holton, Bates and Ruona (2000), has 89 items under which responses were collected through likert scale ranked from

1 - Strongly disagree 2 - Disagree 3 - Neither agree nor disagree 4 -Agree 5 Strongly agree

\subsection{Statistical Tool}

Regression analysis was used to know which factors bring greater changes in outcome scale. This approach was used by Richard, Robert and Frank (2012).

The Durbin-Watson test was used to know for the existence of autocorrelation in residuals in model. Variance Inflation Factor (VIF) is used to checks for multicollinearity.

\section{Analysis Findings and Discussion}

\subsection{Reliability}

Reliability was conducted on sample of 415 , that is, on the basis of final survey. Results are shown in table 4.1. Reliability of all the variables is over $0.7(70 \%)$ and below $.95(95 \%)$.

Table 4.1 Reliability

\begin{tabular}{ll}
\hline Variables & Cronbach Alpha \\
\hline Learner Readiness & 0.740 \\
Motivation to Transfer & 0.810 \\
Personal Outcome Positive & 0.808 \\
Personal Outcome Negative & 0.841 \\
Personal Capacity for Transfer & 0.823 \\
Peer Support & 0.910 \\
Supervisor Support & 0.861 \\
Supervisor Sanction & 0.819 \\
Perceived Content Validity & 0.849
\end{tabular}


Transfer Design

0.829

Opportunity to Use Learning

Transfer Effort-Performance Expectation

0.776

0.837

0.833

Performance-Outcome Expectation

0.925

Openness to Change

0.825

Performance Self-Efficacy

Performance Coaching

Outcome Dependent Variable

0.826

0.881

\section{LTSI Validation in Service Sector $(n=415 / 569)$}

Table 4.2 shows that the value of $\mathrm{R}$ is 0.969 that means there is $96.9 \%$ correlation in variables that are considered in model. The value of $\mathrm{R}$ Square (coefficient of determination) is 0.939 that means that $93.9 \%$ variation (change) in Dependent variable Outcome is brought as a result of Sixteen LTSI variables while $6.1 \%$ variation is as a result of other variables that have not been considered in the study. The value of DurbinWatson Statistic is 2, it shows there is no auto correlation, so variable that are significant are significant without any doubt.

Table 4.2 Model Summary

\begin{tabular}{lccccr}
\hline Model & R & R Square & $\begin{array}{c}\text { Adjusted R } \\
\text { Square }\end{array}$ & $\begin{array}{c}\text { Std. Error of } \\
\text { the Estimate }\end{array}$ & Durbin-Watson \\
\hline 1 & $.969^{\text {a }}$ & .939 & .937 & .18245 & 2.007 \\
\hline & In table $4.3, \mathrm{~F}$ statistic value is 329 that is greater than 4 , and Significance value
\end{tabular}
is .000 that means overall regression model is significant.

Table 4.3 ANOVA

\begin{tabular}{lrrrrr}
\hline Model & Sum of Squares & \multicolumn{1}{c}{ Df } & Mean Square & F & \multicolumn{1}{c}{ Sig. } \\
\hline Regression & 175.408 & 16 & 10.963 & 329.329 & $.000^{\mathrm{b}}$ \\
Residual & 11.318 & 340 & .033 & & \\
Total & 186.726 & 356 & & & \\
\hline
\end{tabular}

Table 4.4 shows, that after applying Linear Regression model on Sixteen LTSI variables to see its impact on dependent variable Outcome; Constant (intercept) has a beta value of 0.167 and significance of $.005(\mathrm{t}=2.81)$. It means when $\mathrm{X}$ (all Sixteen LTSI variables) $=0, \mathrm{Y}$ (Outcome) $=0.167$ and constant (intercept) is significant. Learner Readiness first independent variable has a beta of 0.051 and significance of .000 $(\mathrm{t}=4.432)$. It means one unit change in independent variable Learner Readiness will bring about 0.051 units change in dependent variable Outcome. Motivation to Transfer second independent variable has a beta of 0.049 and significance of $.000(\mathrm{t}=4.8)$. It means one unit change in independent variable Motivation to Transfer will bring about 0.049 units change in dependent variable Outcome and so on. Supervisor Sanction Variable, Performance Outcome Expectation Variable and Performance Coaching Variable are insignificant and do not bring change in dependent variable Outcome. Standardized Coefficients column show that Personal Capacity for Transfer Variable, Peer Support Variable, Supervisor Support Variable and Transfer Effort Performance Expectation Variable have higher Standardized Coefficients betas, that means those variables bring greater change in dependent variable Outcome. There seems to be no multicolinearity problem, as all Sixteen LTSI variables have a Variance Inflation Factor (VIF) of between 1.277 and 3.329, well below five. 
Table 4.4Coefficients

\begin{tabular}{|c|c|c|c|c|c|c|c|}
\hline \multirow[t]{2}{*}{ Model } & \multicolumn{2}{|c|}{$\begin{array}{l}\text { Unstandardized } \\
\text { Coefficients }\end{array}$} & \multirow{2}{*}{$\begin{array}{l}\text { Standardized } \\
\text { Coefficients } \\
\text { Beta }\end{array}$} & \multirow[t]{2}{*}{$\mathbf{t}$} & \multirow[t]{2}{*}{ Sig. } & \multicolumn{2}{|c|}{$\begin{array}{c}\text { Collinearity } \\
\text { Statistics }\end{array}$} \\
\hline & B & $\begin{array}{l}\text { Std. } \\
\text { Error }\end{array}$ & & & & Tolerance & VIF \\
\hline (Constant) & .167 & .059 & & 2.808 & .005 & & \\
\hline $\begin{array}{l}\text { Learner Readiness } \\
\text { Variable } 1\end{array}$ & .051 & .011 & .068 & 4.432 & .000 & .748 & 1.338 \\
\hline $\begin{array}{l}\text { Motivation To } \\
\text { Transfer Variable } 2\end{array}$ & .049 & .010 & .073 & 4.802 & .000 & .779 & 1.284 \\
\hline $\begin{array}{l}\text { Personal Outcome } \\
\text { Positive Variable } 3\end{array}$ & .064 & .013 & .102 & 5.029 & .000 & .436 & 2.294 \\
\hline $\begin{array}{l}\text { Personal Outcome } \\
\text { Negative Variable } 4\end{array}$ & .070 & .014 & .100 & 5.134 & .000 & .474 & 2.108 \\
\hline $\begin{array}{l}\text { Personal Capacity For } \\
\text { Transfer Variable } 5\end{array}$ & .093 & .013 & .133 & 6.901 & .000 & .480 & 2.082 \\
\hline $\begin{array}{l}\text { Peer Support Variable } \\
6\end{array}$ & .083 & .012 & .128 & 6.731 & .000 & .491 & 2.038 \\
\hline $\begin{array}{l}\text { Supervisor Support } \\
\text { Variable } 7\end{array}$ & .118 & .016 & .160 & 7.235 & .000 & .364 & 2.744 \\
\hline $\begin{array}{l}\text { Supervisor Sanction } \\
\text { Variable } 8\end{array}$ & .000 & .013 & .000 & -.016 & .987 & .451 & 2.216 \\
\hline $\begin{array}{l}\text { Perceived Content } \\
\text { Validity Variable } 9\end{array}$ & .079 & .015 & .116 & 5.320 & .000 & .378 & 2.648 \\
\hline $\begin{array}{l}\text { Transfer Design } \\
\text { Variable } 10\end{array}$ & .074 & .010 & .116 & 7.657 & .000 & .783 & 1.277 \\
\hline $\begin{array}{l}\text { Opportunity To Use } \\
\text { Learning Variable } 11 \\
\text { Transferr Effort }\end{array}$ & .055 & .012 & .078 & 4.586 & .000 & .609 & 1.643 \\
\hline $\begin{array}{l}\text { Performance } \\
\text { Expectation Variable } \\
12\end{array}$ & .101 & .014 & .157 & 7.310 & .000 & .388 & 2.580 \\
\hline $\begin{array}{l}\text { Performance Outcome } \\
\text { Expectation Variable } \\
13\end{array}$ & .019 & .016 & .028 & 1.143 & .254 & .300 & 3.329 \\
\hline $\begin{array}{l}\text { Openness To Change } \\
\text { Variable } 14\end{array}$ & .047 & .013 & .076 & 3.656 & .000 & .412 & 2.425 \\
\hline $\begin{array}{l}\text { Performance Self } \\
\text { Efficacy Variable } 15\end{array}$ & .052 & .013 & .072 & 4.049 & .000 & .558 & 1.791 \\
\hline $\begin{array}{l}\text { Performance } \\
\text { Coaching Variable } 16\end{array}$ & .008 & .013 & .013 & .619 & .537 & .425 & 2.353 \\
\hline
\end{tabular}




\subsection{Discussion}

Referring back to the hypothesis developed in Methodology. We accept H1a, H1b, H2a, H2b, H3b, H3c, H3d, H3e, H3f,H4a, H4b, H4c, H4dand reject H2c, H3a, H3g. These results are in consistent with the findings of Chen (2003), except forH2c, H3a. Thirteen of the hypothesis show significant effect on Outcome. Three hypotheses don't show significant effect on Outcome. Performance outcome expectation variable, Performance coaching variable and Supervisor Sanction variable are insignificant and do not bring change in dependent variable Outcome. At the start of the study, it was expected to find an answer to research questions and objectives. Thus after analysis it was revealed that Pakistan service sector employees face problem of improper reward and promotion system, they don't get proper feedback to improve their performance.

Referring back to the objectives of the study, this study has shown impact of motivation scale on outcome scale. Motivation scale constitutes Motivation to Transfer, Transfer Effort Performance Expectation, Performance Outcome Expectation variables. Except for Performance Outcome Expectation remaining two variables brings variation in outcome scale.

This study also shows the impact of environment scale on outcome scale. Environment scale constitutes Personal Outcome Positive, Personal Outcome Negative, Peer Support, Supervisor Support, Supervisor Sanction, Openness to Change, Performance Coaching. Apart from Supervisor Sanction and Performance Coaching variables remaining environment scale variables brings variation in outcome scale. This study also shows the impact of trainee ability scale on outcome scale. Trainee ability scale constitutes Perceived Content Validity, Transfer Design, Personal Capacity for Transfer and Opportunity to Use Learning variables. All trainee ability scale variables bring variation in outcome scale. According to Endedijk and Luyten (2012) learner readiness variables and supervisor sanction variables shows weak or negative or no relations ship at all with dependent variable. HRD practitioners should be careful of the negative impact of elapsed time since training. This study also supports the argument. In this study supervisor sanctions is insignificant while learner readiness show weak relationship with the dependent variable. Bates and Khasawneh (2005) found corporate learning culture has significant associations with all factors except for one factor openness to change factor. Openness to change had negatively correlation with several factors. This study does not support the argument. Reason is the difference in the population structure. Velada, Caetano, Michel, Lyons, and Kavanagh (2007) results show that performance self-efficacy, transfer design, training retention factor and feedback factor were considerably connected to training transfer. On the other hand, supervisor support had no association with training transfer. This study supports the argument except for the fact that supervisory support is also related to training transfer.

\subsection{Conclusion}

In Service Sector, Supervisor Sanction Variable, Performance Outcome Expectation Variable and Performance Coaching Variable are insignificant and do not bring change in dependent variable Outcome. Standardized Coefficients column show that Personal Capacity for Transfer Variable, Peer Support Variable, Supervisor Support Variable and Transfer Effort Performance Expectation Variable have higher standardized coefficients betas, that means those variables bring greater change in dependent variable 
outcome. Supervisor Sanction variable is insignificant because supervisor/managers oppose using techniques employees learned in training. Supervisor advices using different techniques compared to those employees are taught in training. Manager believes employees are not effective while using skills they learned in training. According to various studies including one by Bates and Khasawneh (2005) this variable shows weak or negative or no relations ship at all with dependent variable and needs to be deleted from the model to make the model more accurate and precise. This study also supports the argument.

Performance Outcome Expectation variable is insignificant because Pakistan service sector does not have a proper system of reward. Organization does not value performance of employee. Employees doing average work and employees doing best work are rewarded same way. At times employees who get the reward are those that do not deserve it. When employees enhance their performance they are not encouraged. Job here is not ideal for someone who wants to get rewarded in the form of pay raise, promotion when they improve their performance and perform to the best of their abilities. Service sector management needs to improve their reward system and reward those that deserve it. Performance Coaching variable is insignificant because employees don't get proper feedback and help from supervisors/managers, peers, and customers. Employees get negative feedback from people around on how to improve their job performance. Service sector management needs to have a proper system in place that provide proper feedback and help to employees.

\subsection{Direction for Future Research}

LTSI is a sixteen factor model that gives us a detailed understanding of the learning transfer concepts unlike models like Baldwin \& Ford (1988) that are limited to few factors. Though, LTSI is used in countries like Taiwan (Chen, 2003), South Africa (Coetsee, Eiselen and Basson, 2006), Portugal (Velada, Caetano, Bates and Holton, 2009), and so on; but in developing countries there is a big scope to explore the factors that affect learning outcomes.

\section{References}

Baldwin, T.T., Ford, K.J. \& Blume, B.D. (2009). Transfer of Training 1988_2008: An Updated Review and Agenda for Future Research. International Review of Industrial and Organizational Psychology, 24, 41-70.

Bates, R.A., \& Khasawneh R. (2005). Organizational Learning Culture, Learning Transfer Climate and Perceived Innovation in Jordanian Organizations. International Journal of Training and Development, 9(2), 96-109.

Bersin, J. (2014). Spending on Corporate Training Soars: Employee Capabilities now a Priority. Forbes Magazine, Retrieved from: http://www.forbes.com/sites/joshbersin/2014/02/04/the-recovery-arrivescorporatetraining-spend-skyrockets.

Chen, H.C. (2003). Cross-Cultural Construct Validation of the Learning Transfer System Inventory in Taiwan.Unpublished dissertation, Louisiana State University, Baton Rouge. 
Coetsee, W.J., Eiselen, R. \& Basson, J. (2006). Validation of the Learning Transfer System Inventory in South African Context. South African Journal of Industrial Psychology, 32(2), 46-55.

Devos, C., Dumay X., Bonami M., Bates B. \& Holton E., (2007). The Learning Transfer System Inventory (LTSI) translated into French: Internal Structure and Predictive Validity International. Journal of Training and Development, 11(3), 181-199.

Endedijk, M.D. \& Luyten J.W. (2012). Transfer of and for Learning. A Study on a New Transfer Component and its Influencing Factors. PAACE Journal of Lifelong Learning, 2(3), 23-39.

Grossman, R., \& Salas, E. (2011). The Transfer of Training: What Really Matters. International Journal of Training and Development, 15(2), 103-120.

Holton, E.F. III, Bates, R.A., Ruona, W.E.A. (2000). Development of a Generalized Learning Transfer System Inventory. Human Resource Development Quarterly, 11(4), 333-360.

Hutchins, H. M., \& Burke, L. A. (2006). Has Relapse Prevention Received a Fair Shake? A Review and Implications for Future Transfer Research. Human Resource Development Review, 5(1), 8-24.

Kirwan, C., \& Birchall, D. (2006). Transfer of Learning from Management Development Programmes: Testing the Holton Model. International Journal of Training and Development, 10(4), 252-268.

Richard, F.M., Robert, E.M. \& Frank B.M. (2012). Factors in the Transfer of Governance-Facilitation Skills within Farmers Marketing Organizations in Uganda. Journal of Agricultural Education and Extension 18(3), 231-245.

Riege, A. (2007). Actions to overcome knowledge transfer barriers in MNCs. Journal of Knowledge Management, 11(1), 48-67.

Velada, R. Caetano, A. Michel, J. Lyons, B. \& Kavanagh, M. (2007). The Effects of Training Design, Individual Characteristics and Work Environment on Transfer of Training. International Journal of Training and Development, 11(4), 282-294.

Velada, R., Caetano, A., Bates, R. \& Holton, E. (2009). Learning transfer - validation of the learning transfer system inventory in Portugal. Journal of European Industrial Training 33 (7), 635-656.

Whitebread, D., Coltman, P., Jameson, H., \& Lander, R. (2009). Play, Cognition and Self-Regulation: What Exactly are Children Learning When They Learn Through Play? Educational \& Child Psychology 26(2), 40-52.

Zolingen, S.J. \& Gulen, S.G. (2007). Learning Transfer Measured with LTSI in the Netherlands; Differences Across Organizational Types and Training Types. Human Resource Development Quarterly, 13(6), 37-52. 